\title{
Veterinary Dosage Form
}

National Cancer Institute

\section{Source}

National Cancer Institute. Veterinary Dosage Form. NCI Thesaurus. Code C148243.

Pharmaceutical preparations intended for veterinary use. 